\title{
BEZSENYI TAMÁS
}

\section{Az első magyar sorozatgyilkos bérgyilkosságai II. ${ }^{1}$}

A Szeged környéki tanyavilágban a XX. század első felében egy Pipás Pista nevü napszámos több alkalommal is emberölést követett el. A később ellene indult per és a róla szőtt legendák szerint csak házas férfiakat ölt meg, akik a felbujtó feleségek elmondása alapján iszákosak, erőszakosak és erkölcstelenek voltak.

Az eset főszereplőjének, Pipás Pistának a tanúvallomása két részre osztható: Börcsök István halála kapcsán elöször tagadott, majd nagyrészt beismerte, Dobák Antal ügyében azonban jelentéktelennek tüntette fel a szerepét.

Jelen tanulmányban is a kriminológiai, illetve a kriminalisztikai szempontokat összekapcsolva vizsgálom, hogy Pipás Pista gyilkosságainak történeti tényállását minél aprólékosabban feldolgozva milyen mintákat lehet felfedezni Pipás öléseiben. Az első gyilkosság jelentőségét az adja, hogy Pipás az eljárás kezdetén tagadta az ebben való részvételét, míg Dobákéban nem tagadta, pusztán gyengíteni próbálta. A két eltérő módozat mögött szemléletesen felsejlik, hogy eltérő emocionális háttérrel közelített a két asszonyhoz, valamint családjukhoz.

Börcsöknének, valamint Dobáknénak a tanulmány első részében bemutatott vallomásai alapján látható, hogy az első, rábizonyított emberölés után vissza kívánt illeszkedni abba a rurális társadalmi közegbe, amelyben szocializálódott, míg a második ölése már ennek teljes kudarcát, valamint az egyértelmüen kívülálló (outlaw) szerep elfogadását feltételezi.

Kovács Lajos az emberölések utólagos felderítésének kriminalisztikájával kapcsolatosan kiemeli, hogy az érintettek, az elkövetésben érdekelt személyek között az idő múlásával megváltozó kapcsolatrendszer, későbbiekben kialakuló haragos viszonya elősegítheti egy emberölési ügy sikeres felderíthetöségét. ${ }^{2}$

Pipás Pista ügyében különleges jelentőséget kap ez az érdekelti körben bekövetkező változás, az emberi kapcsolatok felbomlása, mert így vált lehe-

1 A tanulmány első része a 2018/1. számban jelent meg.

2 Kovács Lajos: Az emberölés utólagos felderítésének helyzete és tapasztalatai Magyarországon. Belügyi Szemle, 2005/1., 3-13., különösen 7-9. o. 
tővé, hogy a sorozatgyilkos-jegyek egyre inkább átforduljanak bérgyilkosi magatartássá.

A nemzetközi kriminalisztikai szakirodalom igen elvétve tárgyalja a bérgyilkosságokat, mivel a felderítési dilemmákon túl rendkívül nehéz több cselekményt is kötni ugyanahhoz a személyhez, hiszen tapasztalt bérgyilkosok elöszeretettel változtatnak a modus operandin, az elkövetési módon. Kriminológiai szempontból pedig probléma, hogy az áldozat és az elkövető dichotóm, de szociálpszichológiai szempontból értelmezhető kapcsolatrendszerét újraszabja egy harmadik fél megjelenése, hiszen ekkor az elkövető mint felbujtó már jóval nehezebben azonosítható be egyértelmüen, így a hipotézisek, a gyanúk és a pletykák szegmentálják az adott ügy vagy ügyek elemzésének érvényességét. Schlesinger egészen odáig megy, hogy „, alig megérthetö típusú emberölésnek" tekinti a bérgyilkosságokat. ${ }^{3}$ Calhoun pedig egyenesen egy titkos világ beszüremkedésével magyarázza a hatékony ügyfeldolgozás hiányát. ${ }^{4}$

Pipás ügyében természetesen a Donal MacIntyre, David Wilson és társaik által kialakított tipológiát nem lehet használni ${ }^{5}$, ahogy a korábbiakat sem ${ }^{6}$, hiszen a fizikai jelenlétnek, az erőszak jelentősebb szerepének az adott korszakban nem volt olyan bizonyító ereje, mint a ma, a DNS-, illetve a mikroanyagmaradványok világában. ${ }^{7}$ Pipás kezdetlegesnek tünő módszere ellenére is rendkívül alaposan felkészült, továbbá beállította a helyszínt öngyilkosságnak álcázva. A kor öngyilkosságokra vonatkozó szociológiai diskurzusát nem ismerve, mégis az akasztás módszerével fedte el emberölési szándékát. A módszer hatékonyságát emeli ki Konek Sándor 1867-es megállapítása ${ }^{8}$, illetve a XX. század végén Zonda Tamás és kollégáinak kutatása: meghúzták Nyíregyháza és Pécs között azt a tengelyt, amely alatt, vagyis az ország délkeleti részén az öngyilkosságok száma magasabb, mint északnyugaton, valamint az önakasztás módszerével elkövetett cselekmények is számottevőbbek. ${ }^{9}$

\footnotetext{
3 Louis B. Schlesinger: The Contract Murderer: patterns, characteristics and dynamics. Journal of Forensic Science, no. 5, 2001, pp. 1119-1123.

4 Laurie Calhoun: The phenomenology of paid killing. International Journal of Human Rights, no. 6, 2002, pp. 1-18

5 Donal MacIntyre - David Wilson - Elisabeth Yardley - Liam Brolan: The British Hitman: 1974-2013. Howard Journal of Criminal Justice, no. 4, 2014, pp. 325-340.

6 Louis B. Schlesinger: i. m. 1119-1123. o.

7 Jegesy Andrea - Harsányi László - Angyal Miklós: Az öngyilkosság következtében meghaltak megelőzö egészségi állapota. Népegészségügy, 1995/3., 111-115. o.

8 Konek Sándor: Magyarország öngyilkossági statisztikájához. Statisztikai és Népgazdasági Közlemények és Nemzetgazdasági Szemle, 1867/4., 97-104. o.

9 Zonda Tamás - Paksi Borbála - Veres Előd: Az öngyilkosságok alakulása Magyarországon (19702010). KSH, Budapest, 2013, 29-32. o. [KSH Mủhelytanulmányok 2.]
} 


\section{Az utólagos felderítés problematikája}

Az 1932. július 22-én felvett tanúvallomásában Pipás ${ }^{10}$ annyit ismer el, hogy a haláleset után az áldozat fia, Börcsök Ferenc szólt neki az apja haláláról, és arra kérte, menjen el a rendőrségre jelenteni a halálesetet. Ezután Börcsökékhez ment, ahol egy szekér elé lovat fogatott be, és elment értesíteni a hatóságokat. Más semmit nem tud mondani az esetről. Továbbá azt is tagadja, hogy Dobáknénak említette volna a Börcsök halálában való bünrészességét.

Habár az eset után tizenhárom évvel nyilatkozik, Pipás mégis emlékszik, ki szólt neki Börcsök haláláról, de Börcsökné a vallomásában nem nevezi meg egyértelmüen az illetőt. Továbbá arra sincs magyarázat, mi szükség volt Pipást a Börcsök-tanyára (vissza)hívni, ha már ott volt Török János, Börcsökné bátyja és Ótott Kálmán szomszéd is.

1932. július 30-i második vallomásában már" elismeri bünösségét, és részletesebb vallomással szolgál. A Börcsök Istvánnéval való megismerkedését 1916-ra teszi, amikor a közelükben lakott és többször vetőmagot is cserélt Börcsök Istvánnal. 1919 elején egyezett meg Börcsöknével, hogy odamegy a tanyájukra lakni, amiért ötvenezer koronát fizetett. Saját elmondása szerint három héttel korábban költözött oda, de már hónapokkal korábban panaszkodott az ura iszákosságára és elviselhetetlen magatartására. Pipás elmondása szerint Börcsökné ajánlgatta a gyilkosságot mondván, a férje az ital miatt úgyse élne sokáig, ő pedig adna érte búzát, kukoricát és egyéb dolgokat. Sőt megígérte Pipás lányának a kiházasítását is. Az asszony többször zaklatta az akasztás gondolatával, Pipás szerint maga Börcsökné ajánlotta, hogy egy társat is fizet, és a kötél is az ö ötlete volt, mivel ezzel a legkönynyebb az öngyilkosság látszatát kelteni.

Vecsernyés János felbérlését úgy meséli el, ahogy maga Vecsernyés, de arra már nem emlékszik pontosan, vajon Börcsök Imre együtt ment-e velük a Börcsök tanyára, vagy csak ketten mentek. Arra sem emlékszik, ő vagy Börcsök Imre zaklatta-e fel a lovakat. A hangra azonban kijött egy lámpával Börcsök István, ekkor Vecsernyés Jánossal egészen az udvarig dulakodtak, ahol ö a kötelet az áldozat nyakára tette. Vecsernyéssel együtt bevonszolták és felakasztották. Börcsökné kérésére átvitték a kamrába a testet, ott akasztották fel újra. Sem Vecsernyés, sem Pipás vallomásban nem szerepel az a Börcsökné által említett körülmény, hogy már majdnem hajnal van, vagyis

10 CSML VII. 2. b. B5336/1932. Pipás Pista vallomási jegyzökönyve Börcsök István haláláról.

11 CSML VII. 2. b. B5336/1932. Pipás Pista folytatólagos vallomási jegyzökönyve. 
mindez elég kockázatos. Pipás szerint Börcsök Imre is segített a holttest cipelésében, majd a munka végeztével elöször Vecsernyés, majd ő is távozott a tanyáról. De hajnali öt-hat óra felé Börcsök Ferenc felkeltette, és kérte, menjen el a rendőrökért, mert az apja felakasztotta magát.

Börcsökné még aznap azt mondta Rieger Pálnénak, költözzön át a kistanyáról a nagytanyára hozzá. Elmondása szerint egy évig itt élt, és segített a gazdaságban.

Pipás szerint még a háznál volt a halott, mikor Vecsernyés eljött a pénzéért, a Börcsökné által adott pénzt Pipás csak továbbadta társának, de annak pontos összegéröl nem tudott semmit.

Pipás saját elmondása szerint semmit sem kapott Börcsöknétől, mert haragban váltak el, ezért ott maradt az ő rőzséje, illetve az az öt métermázsa és ötven kilogramm búza, amit megkapott, azt az özvegy nem a sajátjából adta ki, hanem Szücs Viktornak a búzáját Pipás vágta, és onnan járt neki ez a menynyiség.

Három nappal korábban, július 19-én tanúvallomást tesz Dobák Antal halála ügyében, amelyben csak részben ismeri el a bünösségét. ${ }^{12}$

A családdal való megismerkedését az első világháború utáni évekre teszi, de pontosan nem jelöli meg. Egy környéken laktak, és később, 1921-ben kéthárom hónapig náluk élt, amíg a szomszédságban lévő tanyát kitatarozta. Ez a tanya is Dobákék tulajdonában állt, Tombácz Piros vallomásából tudjuk, hogy Pipás Pista többszöri engedélyével itt találkozhatott a szerelmével.

Pipás azzal folytatja, hogy ismerős viszonyba került a családdal, így lehetősége volt megtapasztalni a rossz viszonyt a házastársak között. Dobákot ideges, indulatos természetü embernek írja le, aki a családját napi rendszerességgel az örületbe kergette vagy elzavarta otthonról. Tombácz Pirost viselte a legnehezebben, aki akkor eladósorban volt, és emiatt föként a háztól távol vállalt cselédmunkát. Ekkoriban udvarolt a lánynak Császár József, aki sógoránál, Bende Istvánnál lakott egy környékbeli férfi, Kispéter András tanyáján.

Dobákné 1922 elején többször panaszkodott az urára, és elviselhetetlennek tartott élete miatt állt elő azzal az ötlettel, hogy meg kellene ölni a férjét. Ezeket a kijelentéseit Pipáson kívül Bende István és Császár József előtt is megtette. Pipás szerint e két személy egyébként is mindennapos vendég volt a Dobák-tanyán, főként, ha Dobák nem volt otthon, ugyanis az áldozat nem szívelte túlzottan őket.

12 CSML VII. 2. b. B5336/1932. Pipás Pista vallomási jegyzőkönyve Dobák Antal haláláról. 
1922 márciusában, egy vasárnap Dobákné Bende Istvánnal meglátogatta Pipást, hogy áthívják a tanyájukra, ahol már Császár József is várta őket. Itt Dobákné előadta, hogy elhatározta a férje megölését, ehhez keresett segítséget: „nézzed komám, ha úgy lesz, és segítesz a férjem elföldelésében, akkor $1 \mathrm{~mm}$ búzát, 1 sonkát és 28 liter bort fogok neked adni". Ugyanilyen paraméterekben ajánlott fel díjazást Császárnak és Bendének is. Pipás szerint ők hárman kérdeztek rá, miként képzeli a gyilkosságot Dobákné: ,, az anyja ide-oda Istenit, kössétek fel, akkor nem veszik úgy észre, mintha úgy vernétek agyon". Pipás tanúvallomása szerint akkoriban nagyon szegény volt, a betevője is alig volt meg, emiatt úgy válaszolt, hogy hajlandó ott lenni, de nem vesz részt a cselekményben, mert mint Dobákné tudja, ő a halott embert nem fogja meg. Ennél a mondatnál egy valamilyen közös tapasztalatra vagy beszélgetésre hivatkozhatott, ahol előkerült kettőjük között a halál és a halottak kérdése. Ám a Pipás-legendának része a hatóságok előtt is vállalt tulajdonsága, hogy akasztás után a halotthoz csak a segédek nyúlhatnak.

Ezen a megbeszélésen történt a gyilkosság dátumának kijelölése, de vallomása szerint ezután távozott, míg Bende és Császár ott maradt, és valószínüleg az emberölés további részleteit beszélték meg.

A kijelölt idöpontban, ami a megbeszélés utáni második vagy harmadik nap volt, az esti órákban, körülbelül hét-nyolc óra körül megjelent, amikor még csak a három gyermek volt otthon. Bende és Császár kevéssel utána érkezett, majd negyedórával később Dobák maga lépett be elsőként a konyhába, ahol az elrejtőzött Bende és Császár közösen elkapta, és nyakán a kötéllel vonszolták be a szobába. Ott égő lámpa mellett Pipás várt a három gyerekkel együtt, akik azonnal kiszaladtak, mihelyt az apjukat így látták. Dobákné a konyhaajtóban állt, így akadályozva meg, hogy a gyerekein kívül bárki elhagyja a szobát. Pipás nem látta, ki tette a kötelet még a konyhában Dobák nyakára, de Bende István hozta magával. A szobában az áldozatot Császár fogta meg, míg a kötelet Bende átvetve a mestergerendán öt-hat percig húzta. Pipás nem látta, hogy Dobák rúgkapált volna a kötélen lógva, ezért úgy gondolta, már a konyhában elvesztette az eszméletét, attól hogy kötelet tettek a nyaka köré.

Vallomása szerint nem vett részt a gyilkosságban, csak a halál beállta után Dobákné kérésére vette ki Dobák zsebéből a bugyellárisát és adta oda az aszszonynak. Ez olyan momentum, amely megdönti Pipás vallomásának, és legendájának azt a darabját, miszerint sohasem nyúl halotthoz.

Bende leengedte a kötélről a testet, és Császárral együtt kivitték a kamrába. Dobáknéval együtt Pipás is követte őket, a gyermekek is látták, sőt a kamrába 
be is mentek, amikor a testet újra felakasztották. Bende egy szakajtót tett a hulla alá, és többször elmozdította, mintha Dobák rúgta volna ki, illetve a szakajtó körül toporgott, mivel Bende megállapította, hogy ugyanolyan csizmát visel, mint amilyen Dobák lábán van. A test elrendezése után egy hordóból bort szívott ki egy pohárba, és megitta, mintha csak az áldozat tette volna az öngyilkossága előtt. Ezek után mindannyian visszamentek a házba, ahol Dobákné borral kínálta őket, de Pipás szerint ő elsőként távozott a lakásába. Pipás nem említi a halott melletti italozást, amit másik két büntársa egyaránt bevall.

Az eset után két héttel, jóval Dobák temetését követően megkapta Dobáknétól az egy métermázsa búzát, az egy sonkát, valamint huszonnyolc liter bor harmad részét. Ráadásként Dobák tajtékpipája is az övé lett. A másik két büntárs javadalmazásáról közelebbit nem tud, de biztosra veszi, hogy nem hagyták Dobáknénál, hiszen szegény emberek.

Külön kérdésre előadta, hogy a gerenda, amelyre Dobákot felkötötték, bizonyosan festett volt, de a pontos színröl nem tud határozott választ adni; vagy zöld, vagy kék volt. Szintén kérdésre válaszolva közölte, hogy a kapott élelmet felélte, a tajtékpipát viszont egy évvel később eladta egy majsai lakosnak egy kilogramm faggyúért és egy törött pipáért.

Vallomását azzal zárja, hogy a gyilkosságot illetően mindig nyugtalan volt: ,,Szinte vártam, mikor fog a rendörség hozzám egyszer ezért betoppan$n i$." Nem tudható biztosan, ez vajon a megfontolt bünöző félelme a falusi pletykáktól, vagy a bűntudatos elkövető képének megerősítése.

Az ügyben szereplő vádlottak és tanúk között ő az egyetlen, aki nem tud írni-olvasni, ezért az aláirása helyett az ujjlenyomatával, és egy kereszttel jelezte elismerő szándékát. Abban is egyedülálló, hogy nem tudja pontosan a születési dátumát, így az életkora a hivatalos papírokon folyton változott, végül 1886-ot jelölik ki mint legvalószínübb évet.

\section{Büntársak a Dobák-gyilkosságban}

A Dobák-gyilkosságban Pipás két bűntársa nagyrészt egybehangzó tanúvallomást tett. Bende Istvánnak az eljárás alatt több nevére is fény derült (Horváth János, Bende István, Bönde István, Katona István), ám okát tekintve semmilyen információ sincsen. Az 1932. július 23-i vallomásában az ellene felhozott büncselekmények miatti gyanúsítást megértette, magát bünösnek vallotta. ${ }^{13}$

13 CSML VII. 2. b. B5336/1932. Bende István vallomási jegyzőkönyve. 
Vallomása szerint a Dobák-gyilkosság előtt két hónappal ismerte meg Pipás Pistát, kíváncsiságból meglátogatta. Nem fejti ki bővebben, de könnyen elképzelhető, hogy Pipás egyfajta látványosság lehetett a szükebb-szélesebb környezet számára. Később maga Pipás is többször meglátogatta Bendét Kispéter András általa bérelt tanyáján, ahol Császár Józseffel és annak testvérével, Katalinnal élt együtt. Néhány heti ismeretség után felkereste őt Rieger Pálné. A vallomásban a férjezett neve mellett a születési neve Földi Viktorként szerepel, mintha maga a vallomást felvevő rendőr se tudná, hogy nő valójában. A találkozáskor Pipás felveti ,, a jó bolt lehetöségét”, a könnyü pénzszerzés módjaként Dobák Antal megölését tünteti fel. A munka nélküli Bende hajlandó volt rá, ha jól megfizetik. A vallomásából nem derül ki egyértelmüen, vajon ki, Pipás vagy a feleség az értelmi szerzője a gyilkosságnak. Később szólt Császár Józsefnek az ügyről, aki szintén hajlandó volt részt venni benne. Nem derül ki biztosan, hogy Pipás kért egy másik büntársat, vagy Bende saját ötletéről van szó, esetleg önmagát így akarta biztosítani (tudniillik ha a sógora is benne van egy ilyen veszélyes vállalkozásban, akkor számíthat rá veszély esetén). Pipás legközelebb már úgy jön megbeszélni a tennivalókat, hogy előtte egyeztetett Császárral. Ez azt implikálja, hogy akár Bende, akár Pipás vagy Dobákné ötlete volt a további bünsegéd, a tett végrehajtásának koordinálása Pipás kezében összpontosult. Vallomásában leszögezte, hárman fogják akasztással elkövetni a gyilkosságot, ám magának az ölési módnak az ötletadójára már nem emlékezett egyértelmüen, de úgy vélte, Dobákné lehetett, aki egyszer jelen volt egy megbeszélésükön. Éppen ezen az alkalmon ígért a feleség egy bárányt, százezer koronát fejenként, ötven liter bort és egy sonkát.

Többször beszéltek az elkövetés mikéntjéröl Pipással és Császárral is, utóbbi testvére, Bende akkori vadházastársa is hallott sok mindent, de a cselekményben tevőlegesen nem vett részt. A Dobák-tanyánál is jártak, magával Dobák Antallal is találkoztak, de Bende elmondása szerint egyáltalán nem voltak odajáró vendégek, mint ahogy azt Pipás állította. A Dobákkal való első találkozás után a feleséggel és Pipással megbeszélték, hogy Dobákné jelez aznap, amikor a férjével későn jön haza, hogy ők már nyugodtan várhassák a házban.

1922. március 22-én értesítette Dobákné Pipást, aki Bendéhez ment a hírrel: ma este lesz a gyilkosság. Ez az információ is arra világít rá, hogy az ügy valós középpontja és kapcsolattartója Pipás volt. Császár Józsefet is értesítve hárman érkeztek meg a tanyára, a három kisgyerek volt csak otthon. A Bende által beszerzett istrángot Pipás fogta a konyhaajtó mögött, míg Bende és Csá- 
szár úgy helyezkedett el, hogy az előbbi az áldozat testét, illetve a torkát tudja elkapni, mialatt Pipás a nyakára teszi a hurkolt kötelet. Ennek megfelelöen cselekedtek, a szobába becipelve a zöld mestergerendára húzta fel Pipás és Császár, Bende pedig továbbra is Dobák kezét fogta le. Itt Bende megemlíti, hogy zöld volt a gerenda, amit a rendőrök már kérdeztek Pipástól.

Amikor először lefogták, Bende szerint csak annyit mondott, hogy „,Vigyázzatok, a pipám eltörik”. Majd így kiáltott: „, Ne bántsatok.” A gyerekek az akasztást nem is látva kirohantak, az anyjuk viszont a konyhaajtóban állva figyelt. Miután kiszenvedett, leemelték a testet, az egyik kezét Császár, a másikat Bende vitte, miközben Pipás a lábait fogta; így vitték át a kamrába. A két társ fogta a testet, és legjobb emlékezete szerint ő maga akasztotta fel másodszorra. Kért egy szakajtót, amit többször elmozdítva öngyilkosság hatását akarta kelteni. A vádlottak kivétel nélkül egyetértettek a szakajtó létében és szerepében, de nem tudjuk, ki találta ki az ötletet, egyáltalán elökészített ötlet-e, vagy a helyszínen találták ki.

Utána lopótökkel hordóból szívott bort töltöttek, Pipás az öngyújtójával világított. Bende szerint csak a három tettes ivott, vagyis Dobákné nem. Hiába volt már teljes jogúan az ő háza, hiába nézte végig a férje halálát, nem ivott; adódik a kérdés vajon neki nőként nem volt szabad a férje teteme mellett férfiakkal poharaznia, vagy nem volt gyomra ehhez. Minthogy a házba visszatérve már együtt iszik az elkövetőkkel, valószínübb az utóbbi. Az öngyújtó kérdése pedig megkérdőjelezi Pipás vallomását az ő szegénységéről, illetve pénztelenségéről. A Szeged környéki tanyavilágban folytatott kutatómunkánk ${ }^{14}$ részeként helybeli idős emberekkel készítettem interjút, akik vagy látták gyerekként Pipás Pistát, vagy hallottak róla. Rozsnyói Mária említette, hogy az első világháború után többen készítettek töltényekből és egyéb tüzkőféle eszközökből öngyújtókat. Ám ezek az emberek vagy birtokos gazdák vagy állami alkalmazásban lévő emberek voltak. ${ }^{15}$ Nem jelent feltétlenül jómódúságot az öngyújtó birtoklása, lehetséges, hogy amint Dobák tajtékpipája, úgy az öngyújtó is egy felakasztott embertől ,,megszerzett ajándék”.

Miután egy fél pohár bort otthagytak a hordó tetején Dobák utolsó italozását megkreálva, bementek a házba, ahol már Dobákné is csatlakozott hozzájuk, ott javasolta, hogy le kellene venni a birkaól ajtaját, így az állatok majd öszszetapossák a helyszínen a lábnyomokat. Ráadásul a rendőröknek állíthatja, ő erre a hangra ment ki és vette észre férje öngyilkosságát. Dobákné csak

14 Pipás Pista történetéből dokumentum-, illetve játékfilm készül a szerzö közremüködésével.
15 Rozsnyói Mária-interjú. Öreg-Átokháza, 2010. június 30. 
az utóbbi szempontot említette saját vallomásában, és azt is Bendének tulajdonította. Bende szerint Rieger Pálné ment ki elintézni, elrendezni az egészet. Addig ő megkérte Dobáknét, hogy miután a rendőrök elmennek, és a holttestet leszedik, a kötelet szerezze meg valahogy tölük, és égesse el, amilyen gyorsan csak tudja. Felvetődhet a kérdés, miért volt ez ilyen fontos. Egyfelől akkor, ha éppen ilyen kötélből nem volt a Dobák-tanyán, másfelől a kötélre kötött csomó miatt. Ha az akasztókötélen talált csomót a rendörök összevetik a házban egyéb helyen található, bizonyosan az áldozattól származó csomóval, és az nem egyezik, az megdöntheti az öngyilkosság teóriáját. Dobák temetése után Rieger Pálné szólt Bendének arról, hogy Dobákné a kemencébe dobta a kötelet. Vagyis a kapcsolattartás a gyilkosság után is Pipás Pistán keresztül történt.

Bende szerint hárman közösen távoztak éjjel három körül, amikor is megkapták hordóban az ötven liter bort, ebből már Bendééknél két cserépköcsögben megkapta a részét Pipás is. Távozása után Császár Katalin kérdésére közölték, hogy minden rendben van, majd a nő ivott még velük a borból.

Öt-hat nappal a történtek után Rieger Pálnéval közösen Dobáknéhoz mentek a fizetségért, mindketten kaptak egy-egy darabot egy disznólábból, és valamennyi pénzt. Két hét múlva Pipással megint megjelentek, amikor is Bendééknél elosztották a húsz kilogramm rozslisztet.

Császár fizetségéért is Bende ment mindkét alkalommal, vagyis a két férfi kapott annyit, mint Pipás egyedül. Ez azt feltételezi, hogy Pipásnak többet kellett tennie a gyilkosságban, mint egy háromfös elkövetői csoport egyik tagjának. Főként, hogy a gyilkosság után két hónappal Bende már csak egyedül kért Dobáknétól pénzt vagy kenyeret. Az özvegy adott neki ötvenezer koronát és négy-öt kilónyi rozskenyeret. Vagyis habár Pipás a jövedelmi helyzetét tekintve egy szintre sorolta magát Bendével, ő az adatok szerint mégsem szorult rá ilyen adományokra.

Bende azt vallja, semmit sem tud Börcsök István haláláról, csak az önakasztást hallotta. Elképzelhető, hogy nem akart magának vagy Pipásnak ártani azzal, hogy mégis elmond valamit erröl, de tegyük fel, hogy igazat mond; ebben az esetben ő nem is hallhatta Pipás szájából a történetet, vagyis azt Riegerné megnyugtatásképpen egyedül Dobáknénak mondta el. Ha ez igaz, akkor nehezen hihető, hogy az akasztás Dobákné ötlete lett volna. Az egyik büntárs mégis úgy emlékszik, Dobákné javasolta ezt az ötletet, tehát egy merész feltételezéssel élve Rieger Pálné személyében egy igen csavaros eszü bünözőt ismerhetünk meg, aki felajánlja szolgálatait a , kiszolgáltatottnak tünö" feleségeknek, korábbi akasztásaiból egy esetet (bizalmat akar éb- 
reszteni, de önvédelmi okokból nem mond többet) megoszt a kvázi felbujtóval, akit aztán a büntársak elött már valódi felbujtóként tud felmutatni. Bende a vallomásában szinte kivétel nélkül a férjezett nevén említi Pipást, a gyilkosság tervezésénél egy alkalommal viszont ál- és valódi nevével együtt. De ennek hivatalos megfogalmazása miatt nem tudható, hogy ez nem a hivatalos szervek munkája-e.

Császár József 1932. július 25-i vallomásában a terhére rótt cselekményeket megértette, magát bünösnek érzi. ${ }^{16} 1920$ óta Kiskunhalason és környékén élt, amikor 1922 tavaszán elment Horváth Jánoshoz (Császár a vallomásában következetesen így hívja Bende Istvánt), aki az ő testvérével élt vadházasságban. Császártól megtudjuk, hogy Császár Katalin férjezett asszony volt Vecsernyés Ferencné néven. Tehát egy-két hónappal az akasztás elött érkezett, és a haláleset után még három-négy hétig maradt, de eredetileg nem az ügy miatt jött. Érkezésekor Pipás többször járt át Bendéékhez, de ő nem hallotta a gyilkosságról beszélni. Viszont a testvére élettársával több alkalommal vonultak el kettesben sugdolózni.

A gyilkosság előtt négy-öt nappal Bende kétszer is szólt neki arról, hogy

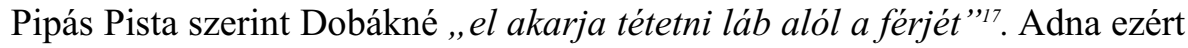
ötven liter bort, egy birkát, gabonát, sonkát és pénzt, de az összegre már a vallomásában nem emlékezett.

Először nem kívánt benne részt vállalni, de a tél miatt régóta nem volt munkája, és így éppen Bende tartotta el. Ez egyszerre magyarázhatja, miért ment a testvére szeretője mellé élni, és miért vállalta a részvételt a gyilkosságban. Császár szerint Pipás a Dobák felakasztása előtti nap is elment hozzájuk a gyilkosság kivitelezéséről beszélni. Vagyis nem csak a tett elkövetése napján ment át Pipás hozzájuk, ahogy azt Bende állította. De Császár és Bende vallomása megegyezik abban, hogy Pipás a gyilkosság estéjén eljött, kettesben beszélgetett Bendével, majd mindketten Császár elé állva kérték a segítségét. Pipás ekkor is megnyugtatta Császárt, hogy Dobákné elrendezett mindent, nekik csak át kell menniük aznap este. Császár vallomásában nem emlékezett rá, ki hozta magával a kötelet, ő már csak Dobák nyakán látta meg. Bende hangsúlyozhatta ugyan a saját fontosságát azzal, hogy ő szerezte be a kötelet, de ha tekintetbe vesszük Pipás feltételezhető óvatosságát, akkor Pipás nem akart hozzá köthető nyomokat hagyni, ha Dobákné esetleg mégsem tudja a kötelet elégetni. 
A Dobák-tanyára érve csak a három gyereket találták otthon, Császár szerint Pipás megkérdezte tőlük, hol az apjuk, ők pedig azt mondták, hogy a szomszédban. Egy ilyen helyzetben érdemes feltenni a kérdést, ki szólítja meg a gyerekeket; minden valószínüség szerint az, aki a legtöbbet találkozik velük, és nem érzik idegennek. Ez megkérdőjelezi Pipás azon állítását, hogy Bende és Császár gyakorta járt a házhoz. Császár szerint a gyerekeknek nem mondtak semmit, a szobában beszélgettek, amíg ők játszottak. Este kilenc óra felé az egyik kisgyerek a kutyaugatás miatt kiszaladt az udvarra, és visszatérve szólt a három férfinak, hogy közelednek a szülei.

Lépéseket hallva Pipás Császárt és Bendét kiküldte a konyhába, ahol az elöbbi a szabadkémény alá, a másik az ajtó mögé rejtőzött. Pipás a szobában maradt, Bende a bejövő Dobáknak a kezét kapta el, Császár pedig a torkát, hogy könnyebben tudják a szoba felé tuszkolni. Onnan lépett elő Pipás, Császár szerint a kabátja alól elővette az instrángot, amit meghurkolva Dobák nyakára tett, és meghúzta. Pipás a mestergerendán átdobva a kötelet Császárral együtt felhúzta a testet. Bende lefogta a testet, mert Dobák le akarta szedni a nyakáról a kötelet. A három gyerek kiszaladt az udvarra, Császár emlékezete szerint tízpercnyi küzdelem után vették észre az áldozat halálát. Dobákné Pipásnak szólt, vegye ki a férje zsebéből a pénzt. Ki is vette, odaadta a nőnek, majd leeresztették a testet, és kint a kamrában Bende kötötte fel. Arra nem emlékezett, ki hol fogta, de mindannyian vitték. Ez némiképp megkérdőjelezi Pipás állítását, miszerint nem nyúl halotthoz. Illetve Dobákné kérése Császár vallomásában is egyértelmüen Pipásnak szólt (,,Pipás, vedd ki a zsebéböl a pénzt" $\left.{ }^{\prime \prime}\right)$.

A szakajtó használatát ő is megemlíti, és az utána következő poharazgatást úgyszintén. Dobákné kérésére Pipás és Bende vitt be bort a házba, ahol tovább folytatták az iszogatást, de Császár, a saját elmondása szerint, annyira izgatott volt, már pár pohár bortól berúgott és elaludt. Nem emlékszik, ki keltette fel, de emlékezete szerint hárman mentek hazafelé. A haza vitt bort, az ebből Pipásnak kiadott részt szinte ugyanúgy beszéli el, mint Bende, de sokkal kevesebbre emlékszik, és a Katalin nevü testvére kérdéseit meg sem említi.

Harmadnapra Pipás megjelent náluk, és beszámolt a fejleményekröl, hogy a rendőrök megállapították az öngyilkosságot. Itt szintén a kapcsolattartó pozíciója mutatkozhatott meg, hiszen egyfelöl az általa hozott információkkal meg tudta nyugtatni a büntársait, másfelől fel tudta mérni, kiknek beszélhet-

18 CSML VII. 2. b. B5336/1932. Császár József vallomási jegyzőkönyve. 
tek az esetről, mennyire viselte meg őket, bármilyen formában gyanúba hozták-e magukat.

Császár szerint Bende és Pipás társaságában ő is elment Dobáknéhoz elkérni a javadalmazásukat. A Bende által említett két találkozóból ő csak az elsőn volt ott, ahol emlékei szerint egy darab sonkát kaptak kétfelé vágva. Itt ő is megerősíti, Bendével közösen kapott annyit, mint Pipás. Pár héttel később már távozott Bendééktől, akit egyébként 1927-ben látott utoljára. Ám távozása előtt Bende és Pipás egyaránt megfenyegette, ha bárkinek beszél az esetről, akkor megölik.

Külön kérdésre előadta, ott-tartózkodása alatt Bende elmondta neki, hogy a Tanácsköztársaság idején Kiskunfélegyházán hóhérként müködött. Ezt valószínüleg Pipás is tudta, ezért kérhette fel büntársnak.

\section{Büntárs a Börcsök-gyilkosságban}

1932. július 30-i vallomásában a vádat megértette, a bünösségét elismerte. Saját elmondása szerint tizenegy-tizenkét éves kora óta ismeri Pipást, mert ekkor kezdett dolgozni nála. Ottlétéről annyit jegyez meg: Pipás ,, mindig úgy szerepelt, mint férfi és férfiruhában is járt, de sokan beszélték, hogy tulajdonképpen nö"'19. Vecsernyés 1900-ban született tehát az 1910-es évek elejéröl beszélt így, vagyis Pipás már a férjével való együttélése idején is férfiként viselkedett.

1919 májusában Pipás felkereste Vecsernyést a lakhelyén, és közölte vele, nagy összeget kereshet, ha segít Börcsök István felakasztásában. Vecsernyés konkrét összeg megbeszélése nélkül egyezett bele munkanélkülisége miatt (is). 1922. május 22-én este jött el újra Pipás, közölte Vecsernyéssel, hogy most fogják megölni Börcsök Istvánt. A tanyára 23 óra tájban értek, de ott emlékezete szerint nem találkoztak Börcsök Imrével. Éjjel háromig vártak, mikor Pipás ütögetni kezdte a lovak fenekét, ennek a hangjára jött ki Börcsök István. Vecsernyés megpróbálta lefogni ugyan, de verekedéssé fajult a helyzet már az udvaron, ahol Pipás fogta le a férjet, majd Vecsernyéssel viszszacipelték az istállóba. Pipás az alacsony gerenda ellenére felakasztotta Börcsököt. Vecsernyés nem emlékszik, mikor került elő a kötél, arra se, hogy Pipás magával hozta-e egyáltalán, vagy ott szedte össze. Az akasztás idején látta meg először Börcsök Imrét is.

19 CSML VII. 2. b. B5336/1932. Vecsernyés János vallomási jegyzőkönyve. 
Vecsernyés vallomása alapján a gyilkosságot nemcsak hogy Pipás maga készítette elő és koordinálta, hanem a verekedésnél is az ő segítségével lehetett a gyilkosságot befejezni. Körülbelül negyedóra múlva vették le, és vitték át a kamrába, ahol megint Pipás húzta fel, amíg Vecsernyés a testet emelte. Ezután Vecsernyés állítólag azonnal hazament, tehát nem maradtak tovább a házban, ahogy azt Börcsök Istvánné vallotta.

Egy héttel később jött el újra érdeklődni, Pipás ekkor adott neki ezer koronát, amit Vecsernyés elmondása szerint addig tartogatott, míg teljesen értéktelen lett. Pipásról mást nem tudott meg, azt sem, vajon Pipás biztatta-e fel Börcsöknét a gyilkosságra, vagy fordítva. Mindkét esetben a büntársak egyetértettek abban, hogy Pipás tette fel az áldozatokra a kötelet.

Az áldozatok családjában lévő gyerekek tanú-, illetve Börcsök Imre esetében vádlotti vallomásai nem tartalmaznak további releváns információkat. Egyetlenegy szempontból fontos Börcsök Imre és Dobák Mária vallomása, mindketten az egész esetből leginkább Pipás Pistára emlékeznek, és büntársainak időnkénti megemlítésétől eltekintve emlékeikben az esemény egészére ráülepedett a férfias Pipás Pista személye. ${ }^{20}$ Ennyiben teljesen illik rá a John Money-féle transzszexuális-definíció, ugyanis ,,az egyik nem morfológiai és szaporodási sajátosságaival rendelkezik, miközben kitartóan a másik nem szerepeire és kiváltságaira tart igényt ${ }^{, 21}$.

\section{A sorozatgyilkos mint bérgyilkosságokat elkövető értelmezése}

Milyen feltételek okozhatták és ezzel párhuzamosan segíthették elő Rieger Pálné Fődi Viktória átváltozását Pipás Pistává? René Grémaux a férfivá vált nőket elemezte a Balkánon történt esetek ${ }^{22}$ segítségével, ő a Pipáshoz hasonló nőket ,átlépetteknek” nevezte. Ezzel a konkrét ruhaváltás mellett a szellemi metamorfózisra utalva, ám a szó ilyetén használata mégis valamiféle befejezettséget sugall, ami ezekben az esetekben inkább kérdéses, mintsem magától értődő. Emiatt is érdemesebbnek látom magyarul átlépőkként hivat-

20 CSML VII. 2. b. B5336/1932. Börcsök Imre vallomási jegyzökönyve, Dobák Mária tanúkihallgatási jegyzökönyve.

21 John Money: A transzszexualizmus és a feminológia elvei. In: Evelyne Sullerot (szerk.): A női nem tények és kérdőjelek. Gondolat Kiadó, Budapest, 1983, 249-257., különösen 249. o.

22 René Grémaux: Woman becomes man in the Balkans. In: Gilbert Herdt (ed.): Third Sex Third Gender - Beyond Sexual Dimorphism in Culture and History. Zone Books, New York, 1994, pp. 241-284. 
kozni rá. Ám az igazi probléma, hogy nem tudja megindokolni, miért fordulnak elő ilyen nagyszámban Kelet-Európában ezek a típusú nők. Egyáltalán valóban csak kelet-európai sajátosságról van-e szó?

Átmeneti ritusok ${ }^{23}$ címü könyvének A materiális átmenet címü fejezetében Arnold von Gennep használja a hasonlatot az országok határaival kapcsolatban, amely szerint a modern kori országhatárok alapján a különböző államok „összeérnek”, de ezeket a királyságokat a korai feudalizmus évszázadaiban egy széles, semleges sáv vette körül. Ezek a földsávok egyes kultúrák számára szentnek számítottak, de minden esetben különösnek minősültek az ott-tartózkodók, hiszen két ország (világ) határán voltak. Ennek a konkrét helyzetnek a megfelelőjét megtalálta olyan vallási, mágikus és profán helyzetekben, amelyeket összefoglalóan határhelyzeti rítusoknak nevezett, ennek részei az elválasztó, határhelyzet alatti és a befogadó rítusok. Diszkurzív szómágiával úgy fogalmazhatunk Pipás Pista „többszörös határsértö”, aki a szerb-magyar határon élt ${ }^{24}$, és biológiailag nőként társadalmi nemét férfira kívánta változtatni. Többszörösségének utolsó ,,szorzója ” a bünözői karrierje mint a társadalmi szabályok megsértője.

Grémaux értelmezésében az úgynevezett átlépők megteremtődésének strukturális előfeltétele a férfi szerepének és a maszkulinitásnak az óriási tisztelete a kultúrában. Egy háztartás - ha társadalmi, gazdasági, morális és kulturális tényezők összességének fogadjuk el - halálra van ítélve, ha eltünik belőle a férfi örökös. Grémaux-nak az e gondolatot kifejtő értelmezésével (,,Egy-egy ilyen család státusvesztést szenved el a közösségén belül...”) nem teljesen értek egyet, hiszen a jól kiházasítható lány is jelenthet értéket, ahogy a Nagy-Alföldet néprajzi szempontból „megfogalmazni” kívánó Kiss Lajos is állítja. ${ }^{25}$

Grémaux további vitatható megállapításai remek értelmezési lehetőséget adnak Pipás magánéletének megértéséhez. A tradicionális kontextusban a „,maszkulinizált nök” összekapcsolódnak az örökké tartó szüzességgel, mivel a maszkulinitás és a szüzesség is ugyanazt jelképezi, a tisztaságot és az erőt. A szüzesség praktikus hozadékának tekinti, hogy megóvja a nőket a törvénytelen gyerekek lehetőségétől, míg a férfierőhöz kapcsolja, hogy a gyerekek

\footnotetext{
23 Arnold van Gennep: Átmeneti rítusok. L’Harmattan-MTA Néprajzi Kutatóintézete-PTE Néprajz Kulturális Antropológia Tanszék, Budapest, 2007, 54-55. o.

24 Kutatómunkánk során Tompa egykori cigánysorán ráakadtunk id. Fliber Antalra, aki Fliber Józsefnek, a szóbeszéd szerint Pipás Pista kocsistársának a fia. A beszélgetéskor elmondta, hogy az apjával rengeteg árut cseréltek át Szeged és Szabadka között. Ez az eufemisztikus megfogalmazás nagyrészt csempészetet takart. Fliber Antal-interjú. Tompa, 2010. július 4.

25 Kiss Lajos: A szegény emberek élete, 2. kötet. Gondolat Kiadó, Budapest, 1981, 343-384. o.
} 
első számú kreátora a férfi. Noha Grémaux-val ellentétben úgy gondolom, a tradicionális kultúra inkább köti a szüzességet a bün előtti állapothoz, mint a férfierőhöz (jó példája ennek a hajadon fogalma és képe), maga Grémaux is a bizonytalanság és az egyenetlenség figyelembevételével kapcsolja össze a maszkulin nőket a szüzességgel, hogy feltehesse a kérdést: vajon ezek a „,szüzek” mindig tartózkodni kívántak a férfiakkal folytatott szexuális élményektől, vagy inkább jobban élvezték a szexualitás szabadságát?

A heteroszexualitás hiányának ennyire plasztikus megjelenése inkább kérdéses Pipás esetében, az elmeorvosi vizsgálatának első részében Pipás közlései jelzik ezeket a problémákat. ${ }^{26}$ Valószínúleg 1886-ban született SzegedÁtokházán, de sem a hónapot, sem a napot nem tudja. Apja és anyja az eljárás idején már elhalálozott, az előbbi gutaütésben, a másik száraz hektikában, az öt testvéréből pedig csak ketten nőttek fel. András testvére azonban Ember Judit kutatásai szerint felakasztotta magát, de ezzel nem Pipást gyanúsították, mivel a fiú többször emlegette öngyilkos gondolatait. Állítólag testi és szellemi fogyatékos és süket volt, és haláláig Pipás gondozta. ${ }^{27}$

Tizenöt-tizenhat éves koráig pásztorként dolgozott, mígnem tizenhét évesen feleségül vette Rieger Pál, akit az elmondása szerint sohasem szeretett, a szülei erőltették a házasságot. A férjével való szexuális együttlétet egyáltalán nem élvezte; hat gyermeket szült, közülük egy maradt életben. Az együtt töltött hét évben nagyon rosszul éltek, nagy valószínüséggel a férj agresszív viselkedése miatt. A hét év alatt született hat gyerek még egy kora újkori társadalomban is súlyos megterhelés lett volna egy nőnek, az pedig, hogy ebböl csupán egy maradt életben, más kérdéseket is felvet, például, hogy történt-e csecsemőgyilkosság, vagy bármilyen más erőszak. E tekintetben semmilyen adatunk nincs.

„A szegény asszony élete a libapásztorkodással kezdödik" mondattal indítja Kiss Lajos kötetének a nehezen élő alföldi nőkről szóló részét. Nem tudjuk, milyen állatok legeltetését bízták Pipás Pistára (akkor még Fődi Viktóriára), de a Kiss Lajos-i struktúrát követve tizenkét-tizennégy évesen a pásztorkodásból kinőve egy szegény lány cseléd vagy pesztonka feladatokat kap. Pipás viszont még tizenöt évesen is állatok terelésével foglalkozott, elképzelhetö, hogy nagyobb testü jószágokat (marha, disznó, birka) is rábíztak. Ember Judit kutatásai között egy interjúban Rieger Pál egyik, még

26 CSML VII. 2. b. B5336/1932. Pipás Pista/Rieger Pálné elmeorvosi jelentése.

27 Ember Judit: Pipás Pista. In: Zalán Vince (szerk.): Az Ember-lépték. Osiris Kiadó, Budapest, 2006, 187. o.

28 Kiss Lajos: i. m. 5. o. 
a Pipással kötött házassága előtt született lánya úgy tudta, Fődi Lukács, Pipás apja juhászember volt. ${ }^{29} \mathrm{~A}$ falusi, tanyasi társadalomban a pásztorkodó emberek kötetlenebb, szabadabb életvitele közismert toposza a népdaloknak, de jelen esetben nem tudjuk, vajon saját állatai voltak, vagy csupán javadalom fejében vállalt pásztormunkát. Ám ha hihetünk Pipásnak, úgy került feleségként egy férj hatalma alá, hogy előtte még soha nem végzett szolgálói munkát, hanem a vele egyidős fiúk feladatát végezte mint állatterelő. Ennek a viszonylagos szabadságnak a vágya elkísérhette házasként.

A Rieger Pállal kötött frigy Kiss Lajos szerint nem nevezhető késői házasságnak Pipás szempontjából, mivel „a szegény ember lánya” közelébe, ha „, otthon tartották”, tizenhat-tizenhét évesen ,, beeresztették a kéröt" ${ }^{\text {" }}$. Rieger viszont ötven körüli ember volt, több gyerekkel, talán öreg korára egy megbízható ápolót kívánt maga mellé, ezért elnézte jövendőbelije rossz szokásait. Pipás saját elmondása szerint tizenhárom éves kora óta pipázott, a kórházban szokott rá, ahol kezelték. A tárgyalásán a bíró kérdésére ismerte el, az orvosok ajánlották neki a betegségére, de később már nem tudta elhagyni. ${ }^{31}$ Tizenöt-tizenhat évesen úgy bedagadt a lába, hogy járni is alig bírt. Utóbbi magyarázat lehet arra, miért éppen ennyi idős koráig foglalkozott pásztorkodással. Saját bevallása ${ }^{32}$ szerint fiatalon többször ivott, részeg is gyakran volt, de soha nem keveredett kocsmai verekedésbe. Ezeknek akár egyike is elég alapot nyújthatott olyan pletykákhoz, szóbeszédekhez, amelyek megnehezítették a házasodását.

Rieger Pál egyik veje úgy nyilatkozott Pipás férjéről, mint nagydarab emberről, aki igen erős volt, az italt és a kártyát is nagyon szerette, de soha nem bántott senkit.

Összességében a házasság rossz tapasztalatai származhattak konkrét erőszakból, vagy csupán az uralkodni vágyó férfi magatartásából, aki a feleségétől egyfajta ,szolgai” magatartást követelt, ez pedig idegenül hatott az évekig szabadon élő pásztorlánynak.

Pipás hét év után megelégelte a helyzetét, saját szavai szerint férfiruhába öltözött, mert úgy gondolta, többet kereshet így. Dolgozott kocsisként, cselédként és napszámos munkában. A büntetöügy miatt kezdeményezett elmevizsgálaton azt vallotta, csak a munka és a jobb fizetség reményében öltözött férfinak.

\footnotetext{
29 Ember Judit: i. m. 151. o.

30 Kiss Lajos: i. m. 148. o.

31 Délmagyarország, 1933. január 11.

32 CSML VII. 2. b. B5336/1932. Pipás Pista/Rieger Pálné elmeorvosi jelentése.
} 
A Pipás-ügy narratíváinak átalakulása vagy további szálakkal való bővülése a korszak sajtójának is tulajdonítható. Az Est 1932. július 24-i számában $^{33}$ a következő címmel jelent meg cikk: Felakasztotta férjét egy pusztamérgesi asszony. - Tíz év múlva derült ki a büne. Július 29-re ${ }^{34}$ már pontosabb információkat szerzett az országos napilap: Miért lett férfi Pipás Pista és hogyan követett el két gyilkosságot? Itt a gyilkosságok helyett már inkább a transzvesztitizmus egyéni indítóokait boncolgatta a cikkíró, föként a férfiak brutális viselkedésével magyarázva a kérdést. A Délmagyarország ugyanezen a napon ${ }^{35}$ inkább az ügyészség dilemmájával foglalkozott: a férfiak vagy a nők közé zárják-e Pipás Pistát? Hiszen nő lévén a férfiakhoz mégsem tehették, de egy nadrágos ember az asszonyok közé se kerülhet, ezért úgy döntöttek, szoknyát adnak rá. A cikk szerint a gyanúsított feszengett az új ruhájában, még fél óra múlva is az övet kereste a szoknyán. A társadalmi nemi hovatartozás szenzációvá emelésén túl plauzibilis magyarázatkeresés helyett az újságírók a brutális gyilkos fogalma alá söpörték az ügyet. A téma 1933 elején került ismét napirendre: január 11-én az ítélethirdetés közeledtével ${ }^{36}$ már $A z$ Est címlapjára kerülő ügyben elsőként a brutális gyilkosok várható súlyos büntetése volt a téma, de ez a következő szövegközi kiemeléssel: „Pipás Pista babos kékszoknyában” bonyolódott. Az Est tudósítója a kegyetlen gyilkos és bünbánó anya fogalmainak antagonizmusát a „,nöiség, mint álca" segítségével oldotta fel.

A január 14-i ítélethirdetést $A z$ Est már csupán a harmadik oldalon hozta, hiába szabtak ki halálos ítéletet Pipásra. A tárgyaláson hallható védő- és vádbeszédek nagyon kevéssé reflektáltak egymásra. Pipás Pista védője, $d r$. Fekete László megállapította: ,Semmi oka nem volt arra, hogy elhagyja a házát [...] társtalanul bolyongjon az országban, férfiruhában. ” Az egész védőbeszédét úgy építette fel, hogy Pipás nem más, mint egy szexuális aberráció áldozata, amit gonosz asszonyok kihasználtak. ${ }^{37} \mathrm{Az}$ ügyész a vádlott nemiségével nem is törődve egy kalap alá vette az összes elkövetőt, és beszéde az előre megfontoltságuk hangsúlyozásában merült ki. ${ }^{38}$

1933 végén Horthy Miklósnak írt kegyelmi kérvényt ${ }^{39}$, ebben nem is mentegette testi és szellemi elváltozását, de az előre megfontoltságot tagadta. Bör-

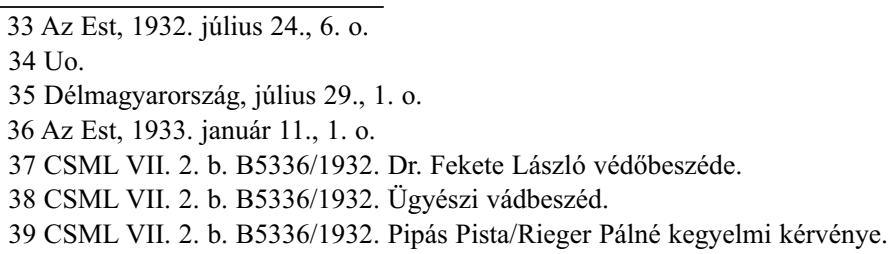


csökné szembesítéskori beismerésére hivatkozott, miszerint a gyilkosságot nem ő találta ki, hanem a feleség. Elképzelhető, hogy a lánya kiházasítása, a tartós megtelepedés reménye miatt döntött a gyilkosság mellett. Ember Judit kutatásában is található egy nő, Kiss Antalné Császár Marcsa, akit Pipás menyasszonyként kívánt magának. A nő elbeszélése szerint meg akarta ölni az urát, hogy együtt élhessen vele, de Kiss Antalné megleste pisilés közben, és így szólt: ,, Meglestem én magát, de magának is csak olyan tepsije van, mint nekem, Pista bácsi. Az uramnak pikulája is van hozzá. Az ember rossz, az igaz, de a pikulája, az jó. Hü de mérges lett! Nem szólt többé énhozzám egész úton." ${ }_{40}$ Minden önállóságra törekvő, vándorló életmódja ellenére lehetett letelepedési szándéka, hogy férfiként egy tanyai háztartás családföje legyen. Börcsökné ennek meghiúsulását Pipás munkakerülésében jelölte meg, maga Pipás csak az összekülönbözést jegyzi meg. Összességében a családi élet kudarcát fordított helyzetben már megélte, most mintha a másik oldalát is megtapasztalta volna.

A Dobák-gyilkosságnál már jelentősebb tervezést igénylö ügyről lehetett szó. A Börcsök esetében még a későbbi együttélés miatt egy az érintettségét igazoló valóságos helyzetet használhatott fel, azonban a Dobák-gyilkosságnál már minden személyes befolyásolásra vonatkozó részlet konfabuláltnak tünt, mivel a családtól eltávolodott az ölés után. Noha minden vallomás megegyezik abban, hogy Pipás járt a legtöbbet mindenkihez információkat hozni, a gyilkosságot megbeszélni. Sőt vele mentek a gyilkosság fizetségéért is. Vagyis az elkövetés legfontosabb organizátoraként teljesíti a bérgyilkosság legfontosabb, főként önvédelmi szempontjait. ${ }^{41}$ Elsőként önkezűségnek állítja be az eseteket, az elkövetéshez használt gyilkos eszköz alkalmi, közvetlenül nem köthető az elkövetőhöz. Általában a bérgyilkos nem ismerkedik meg az áldozattal személyesen, kivéve, ha így tud kapcsolatot teremteni azzal, akinek érdekében áll a kijelölt személy halála.

A statisztikai szempontból a női bünözés magyar aranykorában élő Pipás a gyilkosságokban részt vevőket mind megfenyegette a tettek elkövetése után, így biztosítva a hallgatásukat. Ezzel akár akaratlanul, de akár tudatosan is gerjesztve a tőle való félelmet, ami erősíthette sorozatgyilkosi minőségét mint a paraszti társadalom hierarchiájának felborítóját. Mint már esett róla szó, a XIX. század végén Kraft-Ebing a homoszexualitáshoz sorolta a transzvesztitizmust, mondván a társadalmi konvenciók ellen fellépő magatartásnak minősül.

\footnotetext{
40 Ember Judit: i. m. 164. o.

41 A magyarországi bérgyilkossággal kapcsolatos hiányos információk miatt nagyon hasznosnak bizonyult Kovács Lajos tipológiája és szempontjai.
} 


\section{Elkövetési helyszínek mint a bérgyilkosság felderítését elősegítő információk}

Liam Brolan és kutatótársai egy nagymintás kutatás alapján azt vizsgálták, hogy milyen következtetéseket lehet levonni az elkövetés helyszíne alapján. A legjellemzőbbnek az áldozat otthona (26 százalék) számított, majd az elkerített, nyilvános tér (22), ez után a nyitott tér (19) bizonyult a harmadik legjellemzőbbnek. A kutatásuk alapján látható, hogy a helyszín Pipás Pista ügyét alapul véve nem változott meg jelentősen, inkább a felkészülés módja alakult át, amennyiben a fizikai anyagmaradványok elkerülése érdekében a kontaktust kerülő magatartás gyakori, amelyet az emel ki, hogy előre megtervezett helyröl föként löfegyverrel történik az emberölés. A különbségeket elsősorban az jelenti, hogy nincs szándék az emberölés tényének elfedésére, vagyis a beállított helyszín megalkotására. Ugyanakkor Budvári Róbert egykori, kiváló igazságügyi orvos szakértő tapasztalataira hivatkozva fontos megállapítani, hogy a leplezett emberölések a legritkább esetben adnak arra lehetőséget, hogy felderítsék őket, továbbá listázzák és adatbázist készítsenek abból ${ }^{42}$, ami az igazszolgáltatás inkompetenciájából, intézményesített közönyéből fakadóan csak egy-egy elhivatott kutató számára válik láthatóvá időről időre. ${ }^{43}$

Éppen az igazságszolgáltatási szervek kompetenciahiányának, illetve szervezeti hiátusainak volt a következménye, hogy Pipás Pista úgy vált egyszerre sorozat- és bérgyilkossá, hogy anyagilag volt érdekelt a bosszúálló legendáját felépítő történetekké torzuló, brutális gyilkosságokban.

42 Budvári Róbert: A titkolt emberölés leleplezése. Belügyi Szemle, 1966/6., 52-57. o.

43 Megfontolandó példa Angyal Miklós: Ismeretlen személyazonosságú holttestek kriminalisztikai és szakértői azonosítása. Doktori értekezés. Pécsi Tudományegyetem Állam- és Jogtudományi Kar, Pécs, 2014. 